\title{
DENSITY MANAGEMENT DIAGRAMS FOR STANDS OF Eucalyptus grandis W. Hill RS, BRAZIL ${ }^{1}$
}

Gabriel Paes Marangon ${ }^{2 *}$, Paulo Renato Schneider ${ }^{3}$, Anna Paula Lora Zimmermann ${ }^{4}$, Régis Villanova Longhi $^{4}$ and Jean Pierre Cavalli ${ }^{4}$

\footnotetext{
${ }^{1}$ Received on 10.04.2014 accepted for publication on 27.10.2016.

${ }^{2}$ Universidade Federal de Alagoas, Centro de Ciências Agrárias, Rio Largo, AL - Brasil. E-mail: <gabrimarangon@hotmail.com>.

${ }^{3}$ Universidade Federal de Santa Maria, Centro de Ciências Rurais, Departamento de Ciências Florestais, Santa Maria, RS - Brasil. E-mail:<paulors@smail.ufsm.br>.

${ }^{4}$ Universidade Federal de Santa Maria, Programa de Pós-Graduação em Engenharia Florestal, Santa Maria, RS - Brasil. E-mail:<zimmermann-a@hotmail.com>,<regislonghi@yahoo.com.br>and<jeancavalli@hotmail.com>.

*Corresponding author.
}

\begin{abstract}
Density Management Diagrams (DMD) contribute to the forester, as they allow the understanding of the current situation of the stand, in addition to helping predict its future conditions. The aim of this study is to develop Density Management Diagrams for Eucalyptus grandis Hill ex Maiden, which will serve as auxiliary models for this species, and to establish appropriate density variation, or management zone, for managing stands to be demarcated on the diagram. Full density stands will be used for the study area. The construction of the diagram will be based on the maximum density line (A-line) obtained from fully stocked stands. From this line, stand density indices (B-line and C-line) will be generated in a gradual and proportional manner. The management zone will be made according to the required thinning weight, and afterwards it will generate Density Management Diagram (DMD). This study allowed us to find a possible adjustment of stand density of Eucalyptus grandis Hill, which is fundamental for management of the stand.
\end{abstract}

Keywords: Self-thinning; Management regime; Stand density index.

\section{DIAGRAMA DE MANEJO DA DENSIDADE PARA POVOAMENTOS DE Eucalyptus grandis W. Hill RS, BRASIL}

RESUMO - Os Diagramas de Manejo da Densidade (DMD) contribuem com o silvicultor, pois permitem o conhecimento da situação atual do povoamento, além de contribuir para a predição de condições futuras do povoamento. O objetivo do presente estudo é elaborar Diagramas de Manejo da Densidade para Eucalyptus grandis Hill ex Maiden, que servirão de modelos auxiliares para essa espécie, e estabelecer a variação de densidade adequada, ou faixa de manejo, para condução de povoamentos a ser demarcada no diagrama. Para área de estudo serão utilizados povoamentos em densidade completa. A construção do diagrama será baseada na linha de máxima densidade (linha A), obtida a partir de povoamentos em estoque máximo. A partir desta linha serão gerados os índices de densidade do povoamento (linhas $B$ e $C$ ) de forma gradual e por proporção. A faixa de manejo será gerada de acordo com o peso de desbaste requerido, e após gerar o Diagrama de Manejo da Densidade (DMD). O trabalho executado permitiu encontrar uma regulação da densidade das populações de Eucalyptus grandis W. Hill, essa fundamental para a condução do povoamento.

Palavras-chave: Autodesbaste; Regime de manejo; Índice de densidade do povoamento. 


\section{INTRODUCTION}

In the management of even-aged forests, as the stands grow older, so does the mortality of individuals, which should be avoided with the anticipation of thinning of adequate intensity, which depends on the productive capacity of the site and the growth rate of the trees of the stand (Schneider and Schneider, 2008).

Knowledge of the interrelationships between the tree density per hectare and the growth of their diameter over time are of fundamental importance, because with the aging of the stands there is an increase in the mortality rate of individuals, which should be avoided through thinning interventions proportional to the growth rate of the species (Schneider and Schneider, 2008).

Drew and Flewelling (1979), Tadaki (1963) and Ando (1968) developed the basic principles of Density Management Diagrams (DMD) in similar manners, which are based on the theory of the $-3 / 2$ power rule of selfthinning developed by Japanese scientists for agricultural crops (Yoda et al., 1963). According to this rule, there is a common biomass maximum that an individual plant can reach at any density. Therefore, it is necessary that certain plants die to reach a lower stand density and thus obtain an increase of biomass (Schneider, 2012).

Tang et al. (1994) found that self-thinning starts before the stand, either fully stocked and understocked, reaches maximum density and self-thinning rate increases with the density, reaching the highest rate in a maximum density stand.

The relationship between basal area, number of trees per hectare and average diameter is described by dendrograms of density, known as Density Management Diagrams (DMD), and include a series of reference curves for different density levels of the site (Gezan et al., 2007). Its use allows one to learn the current status of a stand and compare it with predetermined conditions, according to the management purpose previously specified (Rogers, 1983).

Density Management Diagram(DMD) is a technique based on the self-thinning theory, which allows one to view changes in average diameter, height, density and volume of pure even-aged stands (Long and Smith, 1985).

The dendrograms are based on the maximum density curve and from it several proportional parallel lines are made. To do so, the equation that generates the maximum density is modified, multiplying it by a constant ranging between 0 and 1 , and including lines as references to indicate different quadratic diameters (Gezan et al., 2007).

According to Schneider (2012), another method to represent density lines in the dendrogram is the Stand Density Index (SDI). The tree density per hectare, per average diameter, is generated by proportion, based on the tree density per hectare in the standard diameter of $25 \mathrm{~cm}$. The lines are generated for fixed intervals in number of trees (every 200 trees, for example).

Therefore, this study aims to develop Density Management Diagrams for Eucalyptus grandis W. Hill, which will serve as auxiliary models to simulate production for this species and determine the stand density index of stands managed without thinning.

\section{MATERIALAND METHODS}

For the study we will use fully stocked stands with different initial spacings of $1.0 \times 1.5 \mathrm{~m}, 3.0 \times 1.7$ $\mathrm{m}, 2.3 \times 2.3 \mathrm{~m}, 2.0 \times 2.0 \mathrm{~m}$, among others, mostly considered reduced at different ages and sites to enable the preparation of the maximum density line. The data used in this study were from experimental stands, located in two mesoregions of the state of Rio Grande do Sul, the Central east and Porto Alegre Metropolitan area, according to IBGE (Brazilian Institute of Geography and Statistics) (1986).

The climate of the experimental region is Cfa according to Köppen climate classification, with humid temperate climate and hot summers, with average temperature of the hottest month of $25.1^{\circ} \mathrm{C}$, average temperature of the coldest month of $14.1^{\circ} \mathrm{C}$, and average annual rainfall of $1699 \mathrm{~mm}$ (Moreno, 1961).

The soils of the region belong to the Rio Pardo mapping unit, which are deep, reddish throughout the length of the profile, clayey, well-drained and derivative of fine siltstones of the Rio Pardo Formation. These soils have limitations due to low natural fertility. They are highly acidic, with low base saturation, relatively poor in nutrients, with ponderable exchangeable aluminum content (Lemos, 1973).

Studies of density and diameter will be made through the number of trees per hectare and the corresponding average diameter of the trees in the stand. In order to do this, we used the self-thinning model proposed 
by Tang et al. (1994). In the model defined by these authors, the self-thinning rule can be considered a special case because it enables one to obtain density and production for any diameter.

$$
\ln N(t)=\ln S_{f}-\frac{1}{\gamma} \ln \left[\left(D(t) / d_{o}\right)^{\beta \prime \prime}+\delta\right]
$$

Where: $\mathrm{d}=$ quadratic mean diameter of the trees; $\mathrm{N}=$ number of trees per hectare; $\mathrm{t}=$ age of the stand (year); $\beta=$ maximum rate of self-thinning on a fully stocked stand; $\mathrm{N}(\mathrm{t})=$ stand density at time $\mathrm{t}$ (number of trees per hectare); $\mathrm{D}(\mathrm{t})=$ average tree diameter at time $\mathrm{t}(\mathrm{cm}) ; \mathrm{S}_{\mathrm{f}}=$ maximum stand density index; $\gamma=$ selfthinning index; $d_{o}=$ standard base diameter $(25 \mathrm{~cm})$.

In the model of Tang et al. (1994), the constant $\delta$ is determined by the initial density of the stand $\left(\mathrm{N}_{1}\right)$ and the initial average diameter $\left(d_{1}\right)$ in the following formula:

$$
\delta=\left(S_{f} / N_{1}\right)-\left(d_{1} / d_{o}\right)^{\beta \gamma}
$$

According to the model of Tang et al. (1994), previously adjusted to data of trees per hectare by average diameter of the inventoried plots, we determined the Stand Density Indices (SDIs) based on line of maximum density per diameter, which represented the self-thinning level of the stand.

By means of the base and standard diameter of $25 \mathrm{~cm}$, we obtained the Stand Density Indices, through stratifying the densities in proportions. In order to do this, we used SDI intervals of 200, standard diameter of $25 \mathrm{~cm}$, and the following SDI were generated: 1000 , $800,600,400$ and 200 corresponding to the maximum density curve, and its proportions of $55 \%, 50 \%, 45 \%$ and $25 \%$, respectively.

In order to verify the statistical precision of the density and diameter models, we used the adjusted coefficient of determination, the standard error of the estimate and the coefficient of variation, in addition to the Furnival index (1961), which is used to compare logarithmic models that have the dependent variable transformed with arithmetic models (Schneider et al., 2009). According to Aleixo da Silva and Bailey (1991), the Furnival index, with the correct indication for the number of observations and equation parameters, is obtained by the following formula:

$$
\left.F I=\left[\operatorname{antilog}\left(\begin{array}{c}
\Sigma \log Y \\
N
\end{array}\right)\right] \cdot S_{y x} \exp \left[\begin{array}{ll}
N & P
\end{array}\right) / 2 N\right]
$$

Where: FI = Furnival Index; $\mathrm{N}=$ number of observations; $\mathrm{P}=$ number of coefficients; $\mathrm{Y}=$ dependent variable; $\mathrm{S}_{y x}=$ standard error of the estimate.

Linear regressions will be adjusted by PROC REG and non-linear regressions by PROC NLIN in Gauss-Newton and Marquardt method. All procedures used in the calculations are part of the Statistical Analysis System (SAS, 1999) package. For other calculations we used Excel spreadsheet (Microsoft ${ }^{\circledR}$ Ofice, 2003).

\section{RESULTS}

\subsection{Determination of the Stand Density Indices}

The data of average diameter and number of trees per hectare, from permanent plots, in stands set up in several constricted spaces, yielded approximately 107 observations.

The model of Tang et al. (1994) found reasonable statistical values for statistics, such as adjusted coefficient of determination $\mathrm{R}_{\mathrm{Aj}}^{2}=0.7438$, standard error of the estimate $\mathrm{S}_{\mathrm{yx}}=0.2476$ and coefficient of variation $\mathrm{CV} \%=3.1720$.

We defined the self-thinning line for the species in question based on the tree density by diameter model of Tang (1994). The parameters are expressed in the equation of Tang et al. (1994).

$$
\operatorname{In}(\mathrm{N})=\operatorname{In} 978,23-\frac{1}{10,9237} \operatorname{Ln}\left[\begin{array}{l}
\left(\frac{\mathrm{d}-\mathrm{d}_{1}}{25}\right)^{1,6847^{* 10,9237}} \\
+\left(\frac{978,23}{\mathrm{~N}_{1}}\right)^{10,9237}
\end{array}\right]
$$

Therefore, using the equation of Tang et al. (1994), the tree density data per hectare were generated in relation to the average diameter of the stand. With the same equation, we found a decreasing maximum density curve of trees per hectare by the average diameter.

\subsection{The relationship between Production and Stand Density Index}

With the tree density per hectare of the stand previously determined by the density index, basal areas per hectare, and the relationships of volume per hectare in relation to the average diameter per Stand Density 
Index were generated, as shown in Table 1. Thus, in view of the interrelationship of the number of trees, basal area per hectare with average diameter, and the number of trees, average volume per hectare also with average diameter, we were able to construct the density management diagrams.

According to Table 1, one can see that the basal areas present an increase, which was previously expected, according to the increase of the Stand Density Index and similarly for the increase in diameter. We also noted that the basal areas provide a parallel trend within the same density index.

In order to construct the density-volume management diagram, we used a volumetric model to describe the average volume. The statistics show that the equation $\mathrm{Ln} v=\mathrm{b}_{0}+\mathrm{b}_{1} \cdot 1 \mathrm{nN}+\mathrm{b}_{2}$.InG, which estimates average volume in relation to number of trees per hectare and basal area of the stand with parameters $b_{0}=2.227, b_{1}$ $=-1.345$ and $b_{2}=1.765$, presented adjusted determination coefficient of 0.9787 , standard error of the estimate of 0.075 and coefficient of variation of $5.31 \%$, indicating a good statistical precision.
The volumes per hectare in relation to average stand diameter are shown in Figure 1, where it is evident that the highest stand density indices occur in the highest volumetric productions, where the volume per SDIs tended to parallelism with spacing according to increased SDI values, as well as increased diameter, which is the growth structure of even-aged forest stands with a tendency considered normal in overstocked stands.

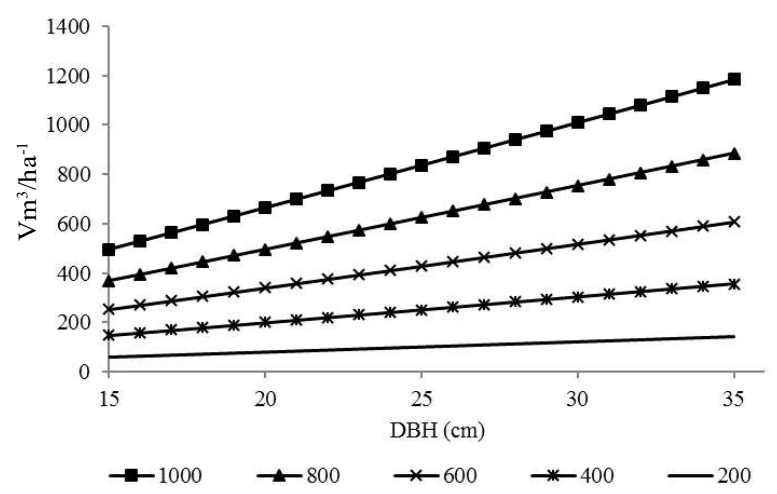

Figure 1 - Volume per hectare in relation to average diameter and Stand Density Index.

Figura 1 - Volume por hectare em função do diâmetro médio e por Índice de Densidade do Povoamento.

Table 1 - Basal area $\left(\mathrm{G} \mathrm{m}^{2} \mathrm{ha}^{-1)}\right.$ and volume $\left(\mathrm{V} \mathrm{m}^{3} \mathrm{ha}^{-1}\right)$ in relation to average diameter and Stand Density Index. Tabela 1 - Área basal $\left(\mathrm{G} \mathrm{m}^{2} \mathrm{ha}^{-1}\right)$ e volume $\left(\mathrm{V} \mathrm{m}^{3} \mathrm{ha}^{-1}\right)$ por diâmetro médio e Índice de Densidade do povoamento.

\begin{tabular}{|c|c|c|c|c|c|c|c|c|c|c|}
\hline \multirow[t]{3}{*}{$\mathrm{DBH}(\mathrm{cm})$} & \multicolumn{10}{|c|}{ Stand Density Index } \\
\hline & \multicolumn{2}{|c|}{ SDI 1000} & \multicolumn{2}{|c|}{ SDI 800} & \multicolumn{2}{|c|}{ SDI 600} & \multicolumn{2}{|c|}{ SDI 400} & \multicolumn{2}{|c|}{ SDI 200} \\
\hline & $\mathrm{V}$ & G & $\mathrm{V}$ & G & $\mathrm{V}$ & $\mathrm{G}$ & $\mathrm{V}$ & G & $\mathrm{V}$ & $\mathrm{G}$ \\
\hline 15 & 495.3 & 45.87 & 369.7 & 36.70 & 253.6 & 27.52 & 149.1 & 18.35 & 60.1 & 9.17 \\
\hline 16 & 528.6 & 46.23 & 394.6 & 36.98 & 270.7 & 27.74 & 159.1 & 18.49 & 64.1 & 9.25 \\
\hline 17 & 562.3 & 46.59 & 419.8 & 37.27 & 287.9 & 27.95 & 169.2 & 18.63 & 68.2 & 9.32 \\
\hline 18 & 596.3 & 46.94 & 445.1 & 37.55 & 305.3 & 28.16 & 179.4 & 18.77 & 72.3 & 9.39 \\
\hline 19 & 630.4 & 47.28 & 470.5 & 37.82 & 322.7 & 28.37 & 189.7 & 18.91 & 76.5 & 9.46 \\
\hline 20 & 664.6 & 47.61 & 496.1 & 38.09 & 340.3 & 28.57 & 200.0 & 19.04 & 80.6 & 9.52 \\
\hline 21 & 698.9 & 47.93 & 521.7 & 38.34 & 357.8 & 28.76 & 210.3 & 19.17 & 84.8 & 9.59 \\
\hline 22 & 733.3 & 48.23 & 547.3 & 38.59 & 375.4 & 28.94 & 220.7 & 19.29 & 89.0 & 9.65 \\
\hline 23 & 767.7 & 48.53 & 573.1 & 38.82 & 393.1 & 29.12 & 231.0 & 19.41 & 93.2 & 9.71 \\
\hline 24 & 802.2 & 48.81 & 598.8 & 39.05 & 410.7 & 29.29 & 241.4 & 19.53 & 97.3 & 9.76 \\
\hline 25 & 836.8 & 49.09 & 624.6 & 39.27 & 428.4 & 29.45 & 251.8 & 19.63 & 101.5 & 9.82 \\
\hline 26 & 871.4 & 49.35 & 650.4 & 39.48 & 446.1 & 29.61 & 262.2 & 19.74 & 105.7 & 9.87 \\
\hline 27 & 906.0 & 49.61 & 676.3 & 39.69 & 463.9 & 29.77 & 272.7 & 19.84 & 109.9 & 9.92 \\
\hline 28 & 940.7 & 49.86 & 702.2 & 39.89 & 481.6 & 29.92 & 283.1 & 19.94 & 114.1 & 9.97 \\
\hline 29 & 975.5 & 50.10 & 728.1 & 40.08 & 499.4 & 30.06 & 293.6 & 20.04 & 118.4 & 10.02 \\
\hline 30 & 1010.2 & 50.34 & 754 & 40.27 & 517.2 & 30.20 & 304.0 & 20.13 & 122.6 & 10.07 \\
\hline 31 & 1045.0 & 50.56 & 780.1 & 40.45 & 535.1 & 30.34 & 314.5 & 20.23 & 126.8 & 10.11 \\
\hline 32 & 1079.9 & 50.79 & 806.1 & 40.63 & 552.9 & 30.47 & 325.0 & 20.31 & 131.0 & 10.16 \\
\hline 33 & 1114.8 & 51.00 & 832.1 & 40.80 & 570.8 & 30.60 & 335.5 & 20.40 & 135.3 & 10.20 \\
\hline 34 & 1149.7 & 51.21 & 858.2 & 40.97 & 588.6 & 30.73 & 346.0 & 20.48 & 139.5 & 10.24 \\
\hline 35 & 1184.7 & 51.42 & 884.3 & 41.13 & 606.5 & 30.85 & 356.5 & 20.57 & 143.7 & 10.28 \\
\hline
\end{tabular}




\subsection{Density Management Diagrams - DMD}

In constructing the Density Management Diagram (DMD), we considered basal area, volume per hectare and tree density in relation to average diameter for each stand density index. These values are shown in Figures 2 and 3.

In the DMD below, we can predict the values of the variables defined by the number of trees in a hectare, basal area in a hectare per average diameter, which will project over time (Figure 2). For the practical application of the Density Management Diagrams, one should initially know the number of trees per hectare and the average diameter of the target stand.

Similarly, Figure 3 shows the combination of dendrometric variables: number of trees per hectare, volume per hectare and average diameter, discriminated by the Stand Density Index.

Therefore, in practical terms, it is understood through Figures 2 and 3 in using the Density Management Diagram that knowing the number of trees per hectare and the average diameter, one can determine the Stand Density Index of a population using the information in Table 1.

In this study of a Eucalyptus grandis stand with different SDIs, one can predict the values of the variables defined by the number of trees in a hectare, basal area

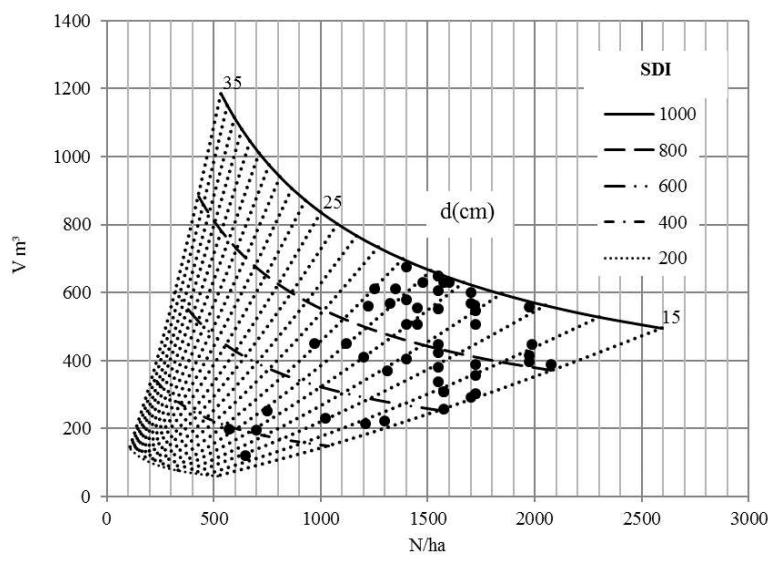

Figure 3 - Density Management Diagram represented by volume, number of trees per hectare with average diameter, all in relation to Stand Density Index and their observed values.

Figura 3 - Diagrama de Manejo da Densidade representado pelo volume, número de árvores por hectare com diámetro médio, todos por Índice de Densidade do Povoamento e seus valores observados.

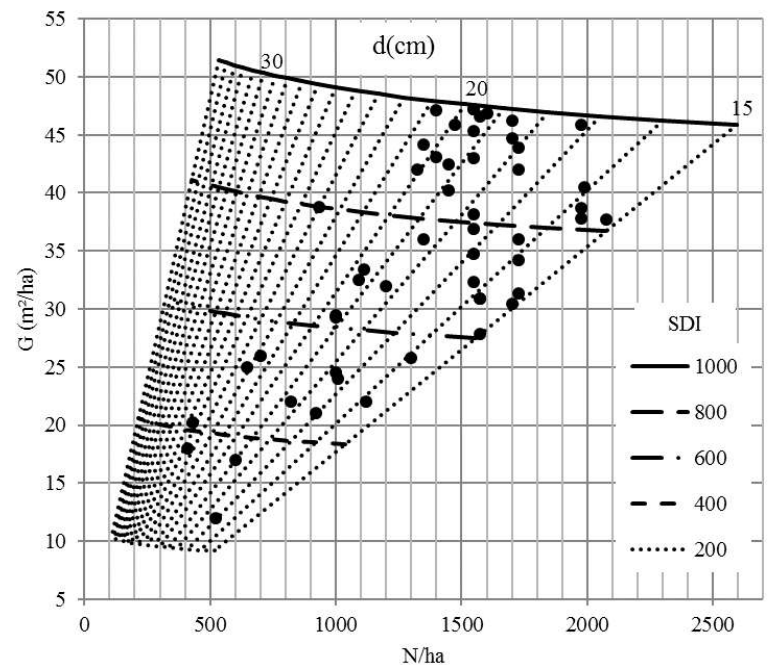

Figure 2 - Density Management Diagram represented by basal area, number of trees per hectare and basal area with average diameter, all in relation to Stand Density Index and their observed values.

Figura 2 - Diagrama de Manejo da Densidade representado pela área basal, número de árvores por hectare e área basal com diámetro médio, todos por Índice de Densidade do Povoamento e seus valores observados.

in a hectare and volume per hectare in relation to average diameter, which will project over time. A practical example would be a Eucalyptus grandis stand presenting an average diameter of $15 \mathrm{~cm}$ and 1558 trees per hectare, which would result in a SDI of 600 with a basal area of $27.52 \mathrm{~m}^{2} \mathrm{ha}^{-1}$ and a volume of $253.6 \mathrm{~m}^{3} \mathrm{ha}^{-1}$ (Table 2).

The efficiency (E) value of volumetric estimates per hectare of the DMD in relation to the actual volumes was 0.83 , which indicates good precision. Similarly,

Table 2 - Prognosis of the parameters number of trees, basal area and volume per hectare in different diameters for a Eucalyptus grandis stand with SDI of 600 .

Tabela 2 - Prognose dos parâmetros número de árvores, área basal e volume por hectare em diferentes diâmetros para uma população de Eucalyptus grandis com IDP igual a 600 .

\begin{tabular}{cccc}
\hline $\mathrm{DBH}(\mathrm{cm})$ & $\mathrm{N}(\mathrm{ha})$ & $\mathrm{G}\left(\mathrm{m}^{2} \mathrm{ha}^{-1}\right)$ & $\mathrm{V}\left(\mathrm{m}^{3} \mathrm{ha}^{-1}\right)$ \\
\hline 15 & 1558 & 27.52 & 253.6 \\
20 & 909 & 28.57 & 340.3 \\
25 & 600 & 29.45 & 428.4 \\
30 & 427 & 30.20 & 517.2 \\
35 & 321 & 30.85 & 606.5 \\
\hline
\end{tabular}

Revista Árvore. 2017;41(1):e410108 
the $x^{2}$ value was 0.00770 , which is not significant at the $0.01 \%$ probability level, thus indicating that the actual volumes per hectare are not statistically different from those estimated in the DMD model, assuring its effectiveness.

\section{DISCUSSION}

Several researchers such as Westoby (1981), West and Borough (1983); Zeide (1985, 1987 and 1991); Smith and Hann (1986); Sterba and Monserud (1993); Yoda et al. (1963); Tang et al. (1994); Osawa and Allen (1993); Tang et al.(1995); Del Rio and t al. (2001) and Farnden (1996) have used and discussed about the self-thinning rule and its efficiency.

In the study of the Picea glauca species in the United States by Puettmann and Saunders (2000), a linear relationship was obtained by the logarithm of tree density in relation to the logarithm of quadratic mean diameter.

In the present study, the curve generated by the equation of Tang is called the maximum density curve, because it represents the maximum tolerance capacity for the trees, shown in Table 1 and Figures 2 and 3 at SDI 1000, where from this point forward they will no longer allow competition among individuals for water, nutrients, living space and so end up dying (selfthinning), which typically affects trees with the worst sociological positions.

In studying Pinus taeda L., Schneider (2008) and Schneider (2012) also used the model of Tang in describing tree density in relation to average diameter and obtained results that corroborate this study.

It is worth noting that the parameter $b_{1}$ of the adjusted equation of Tang did not meet the one recommended by the author, where initially its value would be $-3 / 2$ for all situations of silvicultural management and treatment.

Analyzing Figures 2 and 3, we can demarcate the overstocked management zones (between SDI 1000 and 800) in the two diagrams, which indicate the beginning of mortality caused by competition for water, light, great management zone (between SDI 800 and 400) that represent 45 to $55 \%$ of the maximum line, indicators of the start of maximum wood production of the stand. This is, therefore, a good and desired situation for management, where the variation of the basal area and volume were 41.13 to $18.35 \mathrm{~m}^{2} /$ ha and 884.3 to 149.1 $\mathrm{m}^{3} /$ ha, respectively. Authors such as Cárcamo et al. (2011) have reported in studies of diagrams in Drimys winteri forests in Chile that the maximization of biomass production for energy use is obtained between density indices of $40-55 \%$ and stands located in this area have a lower risk of falling due to wind. Finally, the substocked zone (between SDI 400 and 200) is an undesirable management situation due to the loss of individuals by mortality. Therefore, one cannot get the most out of the soil, with very low stock and trees completely free from competition.

Regarding management zones, Saunders and Puettmann (2000) also identified, in diagrams of Picea glauca, the lines of maximum density, beginning of mortality, beginning of maximum yield, and optimum density range for the species.

According to the statistical results, management strategies and forest planning is possible, as well as the demarcations of possible management regimes to be carried out in the Density Management Diagram (DMD) model, which is used to predict production in volume, basal area, average diameter and number of trees, where each user will determine their thinning strategy. Penner et al. (2006) refer to the density management diagrams as graphical tools, which provide managers assistance as to time and weight in thinning operations.

\section{CONCLUSIONS}

The model of Tang et al. (1994) on the adjustment of tree density per hectare by average diameter of the stand presented reasonable adjustments and statistics, demonstrating with good precision.

The beginning of self-thinning varies considerably with planting density. Therefore, self-thinning occurs in a dimension of average diameter directly proportional to the planting density. This means that the larger the initial spacing is, the larger the diameter will be, and consequently, self-thinning of the stand will take longer to begin;

Maximum values of 1000 to a minimum of 200 were generated in Stand Density Indices, with index class interval of 200 with full coverage of the extent of stand density. It was understood that the curves are proportional to one another with a tendency for the number of 
individuals per hectare to decrease exponentially with the increase in diameter.

Density management diagrams constructed with the variables diameter, basal area and volume per hectare per stand density index were efficient in estimating these values.

\section{REFERENCES}

Aleixo da Silva JÁ, Bailley R.L. Considerações teóricas sobre o uso correto do índice de Furnival na seleção de equações volumétricas. Revista Árvore. 1991;15(3):323-7.

Ando T. Ecological studies on the stand density control in even-aged pure stand. Tokyo: 1968. 153p. (Bull. Gov. For. Exp. Station, 210)

Cárcamo CN, Herrera MA, Aranda FD, Donoso PJ. Diagrama de manejo de densidad y su aplicación a raleo en bosques de segundo crecimiento de Drimys winteri en el sur de Chile. Revista Bosque. 2011;32(2):175-86.

Drew TJ, Flewelling JW. Some recent Japanese theories of yield density relationships and their application to Monterey pine plantations. Forest Science. 1977;23:517-34.

Farnden C. Stand density management diagrams for lodgepole pine, white spruce and interior Douglas-fir. Victoria, BC: Government of Canada, Department of Natural Resources, Canadian Forest Service, Pacific Forestry Centre; 1996. (Information Report BC-X-360)

Gezan AS, Ortega A, Andenmatten E. Diagramas de manejo de densidad para renovales de roble, raulí y coigüe em Chile. Bosque. 2007;28(2):97-105.

Instituto Brasileiro de Geografia e Estatística IBGE. Levantamento dos recursos naturais. Rio de Janeiro: 1986. v.33.

Lemos RC, Azolin MD, Abraão PVR, Santos MCL. Levantamento e reconhecimento dos solos do estado do Rio Grande do Sul. Recife: Ministério da Agricultura. Departamento Nacional de Pesquisas Agropecuárias - Divisão de Pesquisas Pedológicas; 1973. 431p. (Boletim técnico, 30)
Long JN, Smith FW. Relation between size and density in developing stands - a description and possible mechanisms. Forest Ecology and Management. 1985;7(2):191-206.

Moreno JA. Clima do Rio Grande do Sul. Porto Alegre: Governo do Estado do Rio Grande do Sul, Secretaria da Agricultura; 1961. 41p.

Penner M, Swift DE, Gagnon R, Brissette J. A stand density management diagram for balsam fir in New Brunswick. The Forestry Chronicle. 2006;82(5): 700-11.

Rogers R. Guides for thinning shortleaf pine. Buenos Aires: Universidad de Buenos Aires; 1983. p.217-25.

Saunders MR, Puettmann KJ. A preliminary white spruce density management diagram for the lake states. Minnesota: Department of Forest Resources. College of Natural Resources and Minnesota Agricultural Experiment Station. University of Minnesota; 2000. (Sraff Paper Series, 145).

SAS Institute Inc. SAS/STAT user's guide. Version 8 (computer manual). Cary: 1999.

Schneider PSP. Autodesbaste e diagrama de manejo da densidade e povoamentos de Pinus taeda L [dissertação]. Santa Maria: Universidade Federal de Santa Maria; 2008. 94p.

Schneider PSP. Estrutura bioeconômica da produção no manejo da densidade de Pinus taeda L. na região do planalto catarinense, Brasil [tese]. Santa Maria: Universidade Federal de Santa Maria; 2012. 188p.

Schneider PR, Schneider PSP. Introdução ao manejo florestal. $2^{\mathrm{a}}$.ed. Santa Maria: FACOS-UFSM; 2008. 566p.

Schneider PR, Schneider PSP, Souza CAM. Análise de regressão aplicada à engenharia florestal. $2^{\mathrm{a}}$.ed. Santa Maria: FACOS-UFSM; 2009. 294p.

Tadaki Y. The pre-estimating of stem yield bases on the competition density effect. Tokyo: Gov. For. Exp. Station; 1963. 17p. (Bulletin, 154).

Tang S, Meng CH, Meng FR. A growth and selfthinning model for pure even-age stands: theory

Revista Árvore. 2017;41(1):e410108 
and applications. Forest Ecology and Management. 1994(70):67-73.

Tang, S, Meng CH, Meng FR. The impact of initial stand density and site index on maximum stand density index and self-thinning index in a stand self-thinning model. Forest Ecology and Management. 1995;75:61-68.

Yoda K, Kira T, Ogawa H, Hozumi K. Self-thinning in over rowed pure stands under cultivated and natural conditions. Journal Biology. 1963;14:107-29. 